\title{
Role of Changes in Some Adipokines with Obesity in Relation to Thyroid Function in Early Diagnosed Patients with Subclinical Hypothyroidism
}

\author{
ABEER A. ABOZEID, M.D.*; AHMED A. ABD AL-FATTAH, M.D.* and YASSER M. ABD AL-RAOF, M.D.** \\ The Departments of Physiology* and Internal Medicine**, Faculty of Medicine, Tanta University, Tanta, Egypt
}

\begin{abstract}
Background: Thyroid hormones can influence energy metabolism. Many patients of obesity have subclinical hypothyroidism and vice versa.

Aim of Study: To evaluate the relation of changes in the level adipocyte hormones in obesity and in relation to hypothyroid state in early diagnosed patients with subclinical hypothyroidism.

Material and Methods: This work includes 90 females divided into 3 groups each 30 persons (Group I) normal control, (Group II) obese females and (Group III) obese females with early diagnosed subclinical hypothyroidism: BMI were measured and blood samples were collected from all subjects and subjected to determine fasting blood glucose, triglyceride, High Density Lipoprotein (HDL), Low Density Lipoprotein (LDH), TSH, FT4, FT3, insulin level and Interleukin-6 (IL-6). Vaspin, lipocalin 2 and apelin were measured and HOMA IR (homeostatic model assessment) was calculated.

Results: In obese patients' body mass index, TSH, fasting blood glucose, fasting insulin, HOMA IR, Interleukin-6, total cholesterol, triglyceride, low-density lipoprotein and apelin, lipocalin 2, vaspin showed a significant increase with a further significant increase in obese with hypothyroidism compared to control group. A significant decrease in high density lipoprotein in obese females with further significant decrease in obese with hypothyroidism, however, the level of FT3 and FT4 are insignificantly reduced in both obese and obese with hypothyroidism compared to control group.

Conclusion: It is concluded that obesity released adipokines and inflammation may be part of the axis that has a pathogenic role in the development and progression of hypothyroidism in obese subjects. This open a new point of view that disruption of thyroid function may be one of secondary effect of obesity and that disruption of adipocyte secretion of vaspin, lipocalin 2 and apelin may be implicated in some of the metabolic changes associated with obesity and aggravated with hypothyroid state.
\end{abstract}

Key Words: Subclinical hypothyroidism - Obesity - Interleukin 6-Apelin-Vaspin-Lipocalin 2.

Correspondence to: Dr. Abeer A. Abo Zeid, E-Mail: Abeer.Abozeid 2@yahoo.com

\section{Introduction}

ADIPOSE tissue acts as an endocrine organ and plays a great role in the pathogenesis of metabolic syndrome by the secreted adipocytokines [1]. Subclinical hypothyroidism is a compensatory increase in Thyroid-Stimulating Hormone (TSH) levels to preserve normal thyroid hormone levels before they fall below normal and it is considered one of the risk factors causing metabolic syndrome, where Thyroid-Stimulating Hormone (TSH) receptors have been found in the adipose tissue and this indicates that it can perform a central role in the regulation of adipose tissue metabolism [2] . Changes of thyroid hormones in patients with thyroid dysfunction have been previously shown to alter adipocytokines secretion [3]. Vaspin (visceral adipose tissue-derived serpin) is one of this adipocytokine family known as serine protease inhibitor, vaspin is an insulin-sensitizing adipocytokine. Controversial results are reported concerning the role of thyroid hormones in the regulation of vaspin, vaspin mRNA was found to be altered in hypothyroid and hyperthyroid rats [4] . Lipocalin 2 (Lcn2), also known as Neutrophil Gelatinase-Associated Lipocalin (NGAL), is a widely expressed protein that has been found to exert many different functions. Len 2 is involved in inflammation, energy metabolism, and tumor development and progression. It is also known to bind Matrix Metalloproteinase 9 (MMP-9), increasing its stability and its activity, which is important for neutrophil extravasation [5]. Lipocalin-2 has been recently classified as an adipokine because it is produced and secreted by adipocytes [3]. It has been suggested that is has a role in the regulation of energy metabolism also, it is related to insulin resistance, obesity, atherosclerotic diseases and type 2 diabetes [6]. Any change in the thyroid function with alteration in 
thyroid profile can affect the metabolic functions that finally disturb appetite, body weight, and adipose tissue and can also contribute in the pathogenesis of obesity, this interrelation that observed among thyroid function and adipokines production may contribute to the metabolic consequences of thyroid diseases [7]. Therefore, the aim of this work is to investigate the alterations in the level adipocyte hormones vaspin, lipocalin 2 and apelin secondary to obesity and in relation to subclinical hypothyroid state.

\section{Material and Methods}

The study included 90 selected female cases within age range $40-50$ years. They included 30 normal control (Group I), 30 obese females with normal thyroid function selected according to criteria described by Flegal et al., [7] (Group II), and 30 obese females which is early diagnosed with subclinical hypothyroidism (Group III), selected to be newly diagnosed and before taking any treatment. All subjects were subjected to complete history taking and thorough clinical examination. This study was carried out in Internal Medicine Department Tanta University (2018).

\section{Sample collection:}

$10 \mathrm{ml}$ of fasting venous blood samples (overnight from 10-12 hours) were obtained from all subjects under study. A blood portion was collected into dry sterile centrifuge tubes allowed to clot at room temperature for 30 minutes, and then centrifuged for 10 minutes at $3000 \mathrm{rpm}$. Serum clear supernatant was separated from the clot and was stored in sterile aliquots at $-20^{\circ} \mathrm{C}$. Triglycerides (TG), Total Cholesterol (TC), High-Density Lipoprotein Cholesterol (HDL-C), Low-Density Lipoprotein Cholesterol (LDL-C) were measured using enzymatic calorimetric kits with intra-and interassay Coefficients of Variation (CV) of $<10 \%$ (Roche Diagnostics $\mathrm{GmbH}$ ). Fasting glucose concentration was determined by the glucose oxidase method.

The levels of TSH were measured by using method of Ronnov-Jessen et al., [8], Fasting T4, Fasting T3 were assessed [9]. Estimation of insulin level according to Flier et al., [10]. HOMA (homeostatic model assessment) was calculated by Mathews et al., [11]. Interleukin-6 (IL-6) was assessed by Enzyme Linked Immunosorbent Assay (ELIZA). Vaspin was measured by ELISA assay kit: Vaspin EIA Kit/Sigma-Aldrich Co. USA. Serum lpocalin2 were measured by enzyme linked immunosorbent assay technique. sandwich ELISA (R \& D Systems,
Minneapolis, MN, USA). Apelin was measured by ELISA assay kit (MyBioSource, San Diego, CA, USA) rendering to the manufacturer's implications.

A written consent was obtained from subjects under study in accordance with the University Principles of the Faculty of Medicine Ethical Committee.

\section{Statistical methods:}

Results are expressed as mean and Standard Deviation (SD). The intergroup variation was measured by one-way analysis of variance (ANOVA) followed by the Tukey's post-hoc test. The relationship between TSH and vaspin, apelin, and lipocalin 2 was examined by Pearson's correlation coefficient. $p$-values less than 0.05 were considered statistically significant. All the analyses were performed using SPSS for windows (Version 23.0).

\section{Results}

\section{As shown in (Tables 1-3) and Figs. (1,2):}

Body mass index showed a significant increase in obese group (GII) when compared to group (I) with further significant increase in obese with subclinical hypothyroidism (GIII) compared to their levels in the obese group (GII).

Interleukin-6 and TSH showed a significant increase in (GIII) compared to (GII) also in (GII \& GIII) when compared to their levels in the control group (GI), both T3 and T4 are insignificantly reduced in GIII when compared to their levels in GII and in GII \& GIII when compared to their levels in the control group GI (Table 1).

There is a significant increase in the levels of fasting blood glucose, fasting insulin, HOMA IR in (GIII) compared to (GII) also in (GII, GIII) when compared to their levels in the control group (GI) Fig. (1). While apelin, lipocalin 2 and vaspin showed a significant increase in (GIII) compared to (GII) also in (GII, GIII) when compared to their levels in the control group (GI) (Table 2). Also there is significant increase in the levels of total cholesterol, triglyceride and low-density lipoprotein in (GIII) compared to (GII) also in (GII, GIII) when compared to their levels in the control group (GI), while the level of high density lipoprotein showed a significant decrease in (GIII) compared to (GII) also in (GII, GIII) when compared to their levels in the control group (GI) Fig. (2). Table (3) shows significant positive correlation between $\mathrm{TSH}$, apelin, vaspin and lipocalin 2 . 

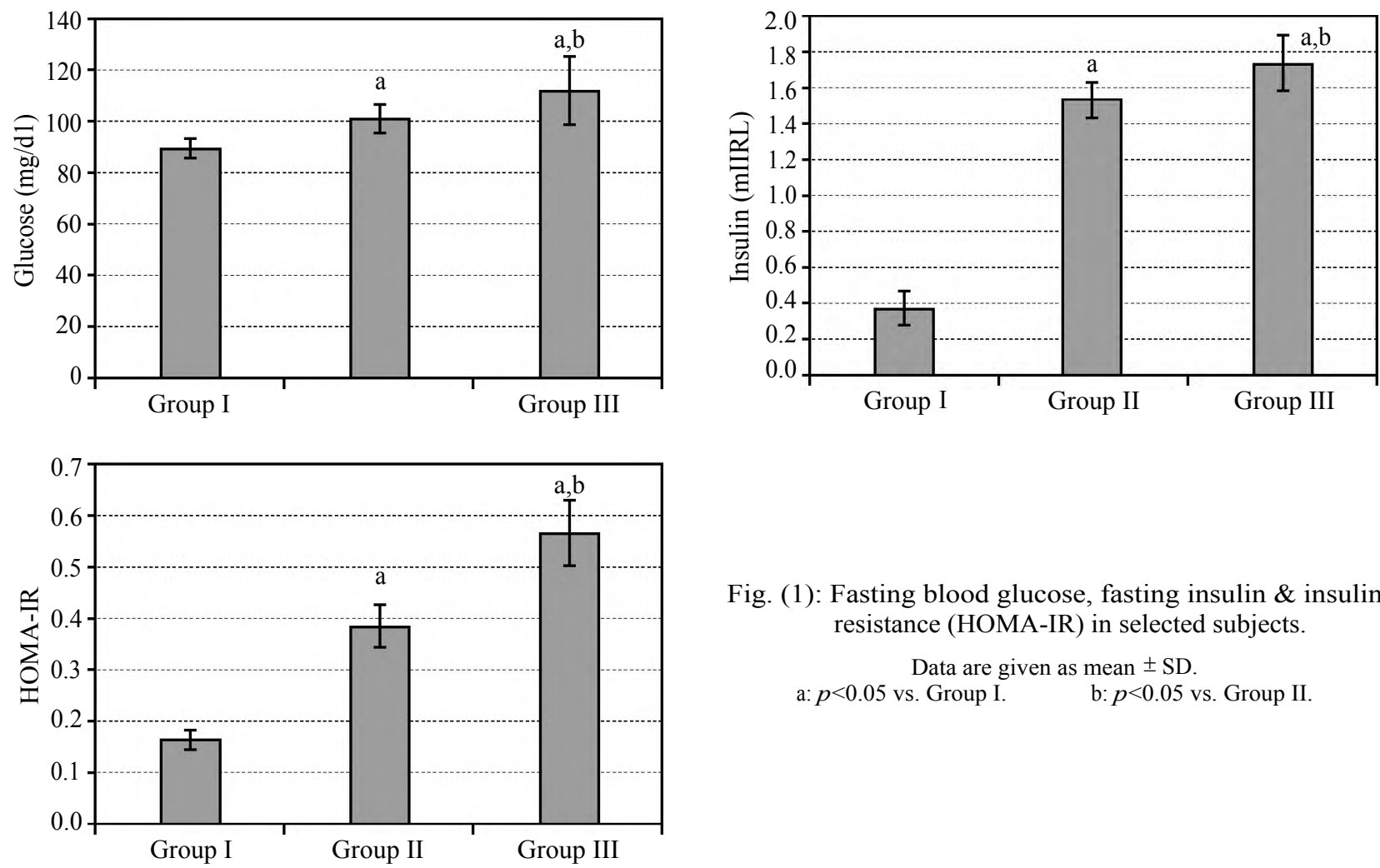

Fig. (1): Fasting blood glucose, fasting insulin \& insulin resistance (HOMA-IR) in selected subjects.

Data are given as mean \pm SD.

a: $p<0.05$ vs. Group I. $\quad$ b: $p<0.05$ vs. Group II.
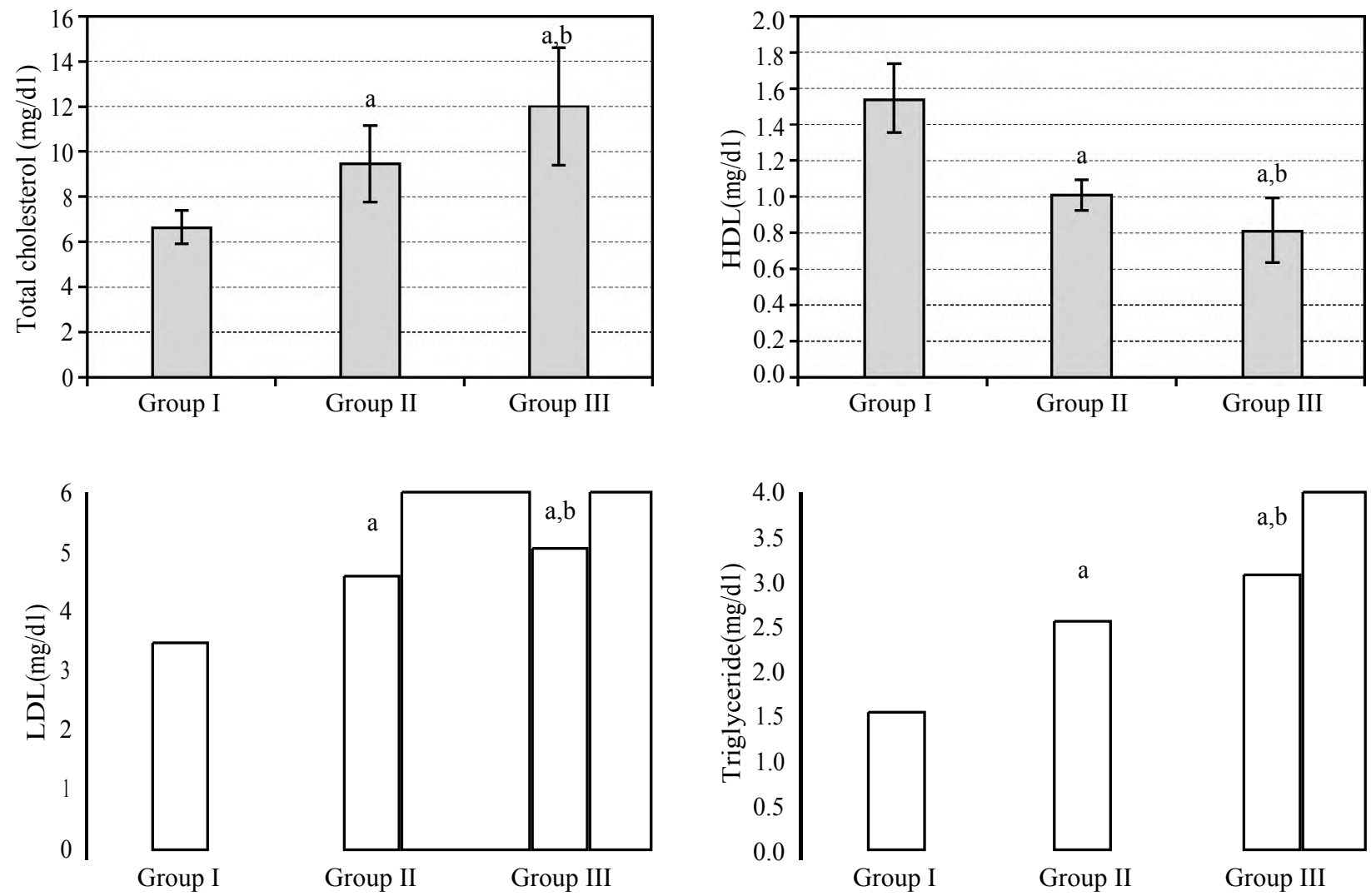

Fig. (2): Level of total cholesterol, high density lipoprotein, triglyceride and low density lipoprotein in selected subjects.

$$
\begin{array}{ll}
\text { a: } p<0.05 \text { vs. Group I. } & \text { b: } p<0.05 \text { vs. Group II. }
\end{array}
$$


Table (1): Body Mass Index (BMI), IL-6, TSH, FT3, FT4 in selected subjects.

\begin{tabular}{llll}
\hline & & \multicolumn{2}{c}{ Obese subjects } \\
\cline { 3 - 4 } Parameters & $\begin{array}{c}\text { Normal } \\
\text { control }\end{array}$ & $\begin{array}{c}\text { Without } \\
\text { hypothyroidism } \\
(\mathrm{n}=10)\end{array}$ & $\begin{array}{c}\text { With } \\
\text { hypothyroidism } \\
(\mathrm{n}=10)\end{array}$ \\
\hline - Body Mass & $26.20 \pm 3.49$ & $32.71 \pm 3.33 \mathrm{a}$ & $38.93 \pm 7.67 \mathrm{a}, \mathrm{b}$ \\
Index (BMI) & & $3.51 \pm 0.31 \mathrm{a}$ & $4.12 \pm 0.37 \mathrm{a}, \mathrm{b}$ \\
- Il-6 (pg/ml) & $2.58 \pm 0.22$ & $3.44 \pm 0.26 \mathrm{a}$ & $6.39 \pm 0.21 \mathrm{a}, \mathrm{b}$ \\
- TSH (U/ml) & $2.15 \pm 0.29$ & $5.61 \pm 0.53$ & $5.40 \pm 0.31$ \\
- T3 (pmol/L) & $5.99 \pm 0.98$ & $12.51 \pm 1.26$ & $12.0 \pm 1.57$ \\
- T4 (pmol/L) & $13.62 \pm 1.43$ & & \\
\hline
\end{tabular}

Data are given as mean $\pm \mathrm{SD}$.

$a: p<0.05$ vs. control group (GI).

$b: p<0.05$ vs. obese group (GII).

Table (2): Vaspin, apelin and lipocalin 2 in selected subjects.

\begin{tabular}{|c|c|c|c|}
\hline \multirow[b]{2}{*}{ Parameters } & \multirow[b]{2}{*}{$\begin{array}{c}\text { Normal } \\
\text { control }\end{array}$} & \multicolumn{2}{|c|}{ Obese subjects } \\
\hline & & $\begin{array}{c}\text { Without } \\
\text { hypothyroidism } \\
(\mathrm{n}=10)\end{array}$ & $\begin{array}{c}\text { With } \\
\text { hypothyroidism } \\
(\mathrm{n}=10)\end{array}$ \\
\hline Vaspin (ng/ml) & $0.82 \pm 0.10$ & $3.31 \pm 0.13 \mathrm{a}$ & $5.52 \pm 0.18 \mathrm{a}, \mathrm{b}$ \\
\hline Apelin (ng/ml) & $1.16 \pm 0.28$ & $3.36 \pm 0.29 \mathrm{a}$ & $4.96 \pm 0.56 \mathrm{a}, \mathrm{b}$ \\
\hline Lipocalin $2(\mathrm{ug} / \mathrm{L})$ & $71.95 \pm 7.62$ & $95.49 \pm 7.52 \mathrm{a}$ & $117.80 \pm 4.67 \mathrm{a}, \mathrm{b}$ \\
\hline
\end{tabular}

Data are given as mean $\pm \mathrm{SD}$.

$a: p<0.05$ vs. control group (GI).

$b: p<0.05$ vs. obese group (GII).

Table (3): Correlation between TSH and vaspin apelin, and lipocalin 2 in group III.

\begin{tabular}{lcc}
\hline \multirow{2}{*}{ Parameters } & \multicolumn{2}{c}{ TSH (U/ml) Group III } \\
\cline { 2 - 3 } & $r$ & $p$-value \\
\hline Apelin (ng/ml) & 0.642 & $0.046^{*}$ \\
Vaspin (ng/ml) & 0.694 & $0.024^{*}$ \\
Lipocalin 2 (ug/L) & 0.732 & $0.016^{*}$ \\
\hline *: Statistically significant. & &
\end{tabular}

\section{Discussion}

Obesity is an important health problem and many studies have suggested a connection between obesity and thyroid function. These studies reported that obesity is generally considered secondary to thyroid dysfunction. Another point of view indicates that changes in Thyroid-Stimulating Hormone (TSH) could well be secondary to obesity, the interrelationships between body weight and thyroid status are complex [12]. In view of the present findings, it is observed that subclinical hypothyroidism in obese cases is associated with significant increase in BMI as compared to obese group.

It was previously reported higher prevalence of obesity in people with hypothyroid disease. And it was reported a significant relationship between serum TSH and BMI and mean TSH increased as BMI increased, this could be due to direct stimu- lating effect of TSH on preadipocyte differentiation which resulting in adipogenesis and fat mass accumulation with positive energy-balance [13]

Obesity impairs adipocyte function where hypo perfusion and hypoxia in adipose tissues results in impairment in the formation of adipokines [14] One of these adipokines is Leptin that seems to be a promising link between obesity and alterations of thyroid hormones. The interrelation between leptin and TSH is bidirectional since TSH stimulates leptin secretion in addition leptin regulates TSH secretion as it promotes thyrotropin releasing hormone gene expression directly in the paraventricular nucleus, ultimately stimulating TSH release [15].

One possible mechanism for the dysregulation of adipocyte is inflammatory reaction. High nutrient milieu may stimulate circulating macrophages that could lead to chronic lower inflammatory state, this results in marked dysfunction in the accumulated lipid both in adipose tissue and the liver with subsequent chronic inflammatory state which is a characteristic feature of obesity [16]

It is evident from the results of the present work that IL-6 is significantly elevated in obese patients when compared to normal control and it was reported that individuals with visceral obesity have higher serum IL6 [17]. In hypothyroid obese females (group III) the level of IL-6 is significantly higher than both normal control and obese group. Subclinical hypothyroidism is described by an elevated TSH level, TSH is a pro-inflammatory stimulus of adipocytes. Increases in lipolysis and in IL-6 expression and release occur in TSH-stimulated adipocytes. TSH stimulates adipocyte IL-6 secretion through a cAMP-protein kinase a pathway and activation of the nuclear factor-kappaB pathway [18]

Diet with high calories with physical inactivity promotes obesity and state of tissue inflammation which result in insulin resistance as demonstrated by the significant increase in HOMA-IR in obese group as compared to normal control. Several mechanisms are involved in obesity induce insulin resistance. Increase IL6 which is a proinflammatory cytokine involved in insulin resistance. Chronic action of IL-6 can prevents autophosphorylation of insulin receptor and downstream signaling mediators in liver [19].

Also in chronic growth of adipose tissue, lowgrade inflammation occurs with consequent infiltration of immune cells that may result in decrease in adipokine excretion, which later leads to systemic insulin resistance [20]. 
HOMA IR is significantly elevated in obese with hypothyroid group as compared to obese alone or normal control subjects. Increase in plasma TSH levels in hypothyroid females may affect insulin secretion and may be combined with insulin resistance since thyroid hormones are involved the insulin resistance state [21]. Aksoy et al., [22] observed in his study increased insulin resistance in cases with hypothyroidism. On the other hand, previous study reported a significant positive correlation between the TSH and insulin levels, also between the TSH and HOMA IR levels [23].

In obese group there is significant hyperinsulinemia and hyperglycemia as compared to normal control group, Insulin resistance in obese persons leads to a lessened clearance of blood glucose beside an increased in hepatic glucose output, both combining to result in elevated plasma glucose this is referred to as the adipo-insulin axis [24].

In group with obese hypothyroidism there is further significant elevation in insulin and blood glucose levels, which could be also explained by reduced glucose metabolism because of diminished insulin depending glucose utilization specially in peripheral tissues as a sequence of impairment in peripheral blood flow [25]. Kapralova et al., demonstrated that increased level of resistin and leptin hormones in cases with subclinical hypothyroidism results in subsequent insulin resistance which results in a compensatory hyperinsulinemia and hyperglycemia [26]

Interactions of macrophages and generation of proinflammatory cytokines can impair metabolic processes in tissues that are physiological targets for insulin. These inflammatory changes may lead to dyslipidemia, which are significant features indicating obesity [27].

It is evident from results of the present work that there is significant increase in total cholesterol LDL, TG and significant decrease in HDL in obese group compared to control.

Obesity as a triggering factor with its characteristic hyperglycemia because of impairment in glucose uptake in the muscle and liver addition to insulin resistance with diminished antilipolytic effect of insulin that increase hepatic cholesterol formation and decreased HDL-C can result in significant increase in total cholesterol LDL, TG and significant decrease in HDL in obese group compared to control [28]
In obese group with subclinical hypothyroidism the dyslipidemia is more intensified. Insulin resistance in addition to thyroid dysfunction increase the risk of dyslipidemia. It has been suggested that insulin resistance expands the harmful influence of hypothyroidism on the lipid profile [29]. The thyroid hormone is one of the hormones that control all metabolic process concerned with lipid metabolism. TSH significantly and positively relates to increase TG through its effect on lipoprotein lipase. Hypothyroidism leads to reduction of the number of LDL receptors in the fibroblasts, liver, and other tissue tissues, so it reduces excretion of cholesterol in bile, thus resulting in elevated serum level of LDL [30]. Thyroid hormones increase 3-Hydroxy3-Methyl-Glutaryl-Coenzyme A (HMG-COA) reductase activity in the liver and, thus reduce cholesterol and alter levels of High-Density Lipoprotein (HDL) cholesterol and hepatic lipase activity and affect the excretion of cholesterol from the intestine by bile acids [31]. On the other hand, it upregulates expression of peroxisome proliferator-activated receptor gamma coactivator-1alpha (PGC-1 a) which is a master coregulator of both glucose and lipid metabolism and an important cofactor for the Peroxisome Proliferator-Activated Receptor a (PPARa) and regulates the transcriptional activation of genes associated with fatty acid oxidation, directly increasing palmitate oxidation rates [32].

Adipose tissue is established as an endocrine organ secreting different adipocytokines contributes in the pathogenesis of metabolic dysfunction complicating obesity [33]. Our study revealed significant increase of vaspin in obese group as compared to control group. Many studies has been implicated to study the role of vaspin as a new adipokine secreted from White Adipose Tissue (WAT) and its relation to obesity, most of results of these studies support the relation of vaspin and parameters of metabolic syndrome and several studies have shown a positive correlation between vaspin gene expression and HOMA insulin resistance, percentage of total body fat and glucose intolerance and revealed that increased vaspin concentration and mRNA gene expression specially in Visceral Adipose Tissue (VAT) is an indicator for obesity [34]. In contrast to this findings other studies show quite contradictory results, as lower vaspin levels have been recorded in men with metabolic syndrome [35] and no significant difference in vaspin levels has been observed in subjects with newly diagnosed T2DM and metabolic syndrome as compared to a group without metabolic syndrome [36]

From the results of our study we can conclude that increase vaspin in obese group is a compensa- 
tory mechanism associated with obesity resulting in excessive secretion of vaspin from (WAT) that is activated and secret vaspin in response to increased HOMA insulin resistance and increased glucose level [37] as well as a low-grade inflammation as evidenced by increased IL-6 stimulate secretion of vaspin from VAT [38].

In group of obesity with subclinical hypothyroidism there is significant increase in the level of vaspin if compared to obese group. There are few studies about the regulation of vaspin by thyroid hormones, and the results of them are controversial, one of this study was in rats and it suggested that thyroid dysfunction may affect vaspin mRNA expression as vaspin mRNA expression is significantly increased in hypothyroid rats compared with the euthyroid ones despite that no change in glucose and insulin concentration [39]. Another study reported that weight loss by bariatric surgery in obese subject resulted in significant decrease in TSH levels in positive correlation with changes in serum vaspin levels [40]. On the other hand, Cinar et al., proved that there is no difference in vaspin levels between euthyroid and hypothyroid subjects (subclinical and clinical hypothyroid), and no significant difference was detected in vaspin levels after normalization of thyroid hormones. Moreover, vaspin levels were not correlated with TSH [41]. The increased level of vaspin in group with obesity with subclinical hypothyroidism can be explained by TSH stimulatory effect on adipose tissue as a result of increased TSH in this group, adipocytes express high levels of TSH receptors and TSH participates in the regulation of adipocyte functions including secreting adipokines [42] and this is confirmed by our finding where is positive correlation between TSH and vaspin level. In addition vaspin expression in adipocyte is mainly linked to adipocyte dysfunction, hypertrophy and lipolysis in visceral and subcutaneous adipose tissue [43]

The level of lipocalin 2 is significantly increased in obese group as compared to normal control group. Obesity is a pro-inflammatory state with elevation of multiple markers of inflammation and different cytokines [44]. This proinflammatory cytokines stimulate Lcn 2 expression in the active adipocyte [45], as well as by the activated hepatocyte [46]. Lipocalin 2 augments inflammation and lipid peroxidation in adipose tissue, which results in more release of proinflammatory cytokine and adipokines from the active adipocyte [47], in addition lipocalin 2 which is iron transport proteins can result in beta cell dysfunction by increasing intracellular iron concentration in it resulting in oxidative stress this impaired insulin secreting capacity of B cells $[48,49]$. In addition, it has been previously proved the exogenous lipocalin 2 increase glucose production by hepatocyte [50] a condition that explain significant hyperglycemia and insulin resistance in obese group and in obese group with hypothyroidism as compared to obese group as the level of lipocalin 2 is significantly increased in subclinical hypothyroidism as compared to obese group alone with positive correlation between lipocalin 2 and TSH. This may be a part of the stimulatory effect of TSH on adipocyte either directly because of enhanced expression of its receptors in adipocyte [42] or may be a part of a reaction mediated by its lipodystrophic effect that activate more inflammatory response that stimulate the release of adipokine form adipose tissue [51].

There is only one study investigates the level of lipocalin 2 with subclinical hypothyroidism in normal weight subject. It revealed no significant difference of serum lipocalin-2 levels between patients with subclinical hypothyroidism and healthy control subjects. However positive correlations were found between serum lipocalin- 2 and BMI [52].

However, Cheng-et al., discovered the stimulatory effect of thyroid hormones on LCN2 mRNA and protein expression in a receptor-dependent manner [53].

Serum apelin level were significantly increased in obese compared to non-obese controls. Dysregulation of apelin, is one of the important causative factors in the development of obesity. Bertrand et al., supports the theory that abnormal production of apelin can contribute to the pathogenesis of obesity. Apelin is positively associated with BMI and has negative correlation with HOMA-IR index [54] . Plasma apelin and insulin levels were found to be significantly elevated in obese patients in addition plasma apelin concentrations and apelin mRNA expression in adipocyte increase in hyperinsulinemia associated obesity [55]

In hypothyroidism with obesity there is further significant increase in apelin level with positive correlation between apelin and TSH this is with accordance with previous study which reported that apelin levels were the highest in the hypothyroid patients. Apelin receptors have been detected in the thyroid gland, increase in the TSH in hypothyroidism may cause an increase the release of apelin [56] 


\section{Conclusion:}

It is concluded that obesity released adipokines and inflammation may be part of the axis that has a pathogenic role in the development and progression of hypothyroidism in obese subjects. This open a new point of view that disruption of thyroid function may be one of secondary effect of obesity and that disruption of adipocyte secretion of vaspin, lipocalin 2 and apelin may be implicated in some of the metabolic changes associated with obesity and aggravated with hypothyroid state.

\section{References}

1- SHASHATY M.G. and STAPLETON R.D.: Physiological and management implications of obesity in critical illness. Ann. Am. Thorac. Soc., 11 (8): 1286-97, 2014.

2- WANG C.Y., CHANG T.C. and CHEN M.F.: Sci. Rep. Associations between subclinical thyroid disease and metabolic syndrome. Endocr. J., 59 (10): 911-7, 2012.

3- CHEN Y., WU X., WU R., SUN X., YANG B., WANG Y. and XU Y.: Changes in profile of lipids and adipokines in patients with newly diagnosed hypothyroidism and hyperthyroidism. Sci. Rep., 19 (6): 26174, 2016.

4- GONZALEZ C.R., CAMINOS J.E., VÁZQUEZ M.J., GARCÉS M.F., CEPEDA L.A., ANGEL A., GONZÁLEZ A.C., et al.: Regulation of visceral adipose tissue-derived serine protease inhibitor by nutritional status, metformin, gender and pituitary factors in rat white adipose tissue. J. Physiol., 587: 3741-50, 2009.

5- JAYARAMAN A., ROBERTS K.A., YOON J., YARMUSH D.M., DUAN X., LEE K., et al.: Identification of Neutrophil Gelatinase-Associated Lipocalin (NGAL) as a discriminatory marker of the hepatocyte-secreted protein response to IL-1 3 : A proteomic analysis. Biotechnol Bioeng., 91: 502-15, 2005.

6- YAN Q.W., YANG Q., MODY N., GRAHAM T.E., HSU C.H., XU Z., HOUSTIS N.E., KAHN B.B. and ROSEN E.D.: The adipokine lipocalin 2 is regulated by obesity and promotes insulin resistance. Diabetes, 56: 2533-40, 2007.

7- FLEGAL K.M., KRUSZON-MORAN D., CARROLL M.D., FRYAR C.D. and OGDEN C.L.: Trends in Obesity Among Adults in the United States, 2005 to 2014. JAMA, 315 (21): 2284-91, 2016.

8- RONNOV-JESSEN D., SKOV L. and FABER J.: Immunoradiometric assay of serum thyroid stimulating hormone (TSH) as a first-line test in a mixed hospital population. Clin. Chim. Acta, 168 (1): 13-7, 1987.

9- KAN ERIKSSON H., JAN NILSSON and BO MATTIASSON: Radioimmunoassay of triiodothyronine (T3) and thyroxine (T4). Applied Biochemistry and Biotechnology, 8 (1): 1-7, 1983.

10- FLIER J.S., KAHN C.R. and ROTH J.: "Receptors, antireceptors antibodies and mechanism of insulin resistance.” N. Engl. J. Med., 300 (8): 413-9, 1979.

11- MATHEWS D.R., HOSKER J.P., RUDENSSKI A.S., NAYLOI B.A., TREACHER D.F. and TURNER R.C.: Homeostasis model assessment: Insulin resistance and
B-cell function from plasma glucose and insulin concentration in man. Diabetologia, 28: 412-9, 1985.

12- VERMA A., JAYARAMAN M., KUMAR H.K. and MODI K.D.: Hypothyroidism and obesity. Cause or effect? Saudi Med. J., 29: 1135-8, 2008.

13- ABDI H., KAZEMIAN E., GHARIBZADEH S., AMOUZEGAR A., MEHRAN L., TOHIDI M., et al.: Association between thyroid function and body mass index: A 10Year Follow-Up. Ann. Nutr. Metab., 70 (4): 338-45, 2017.

14- HOSOGAI N., FUKUHARA A., OSHIMA K., MIYATA Y., TANAKA S., SEGAWA K., et al.: Adipose tissue hypoxia in obesity and its impact on adipocytokine dysregulation. Diabetes, 56 (4): 901-11, 2007.

15- SANYAL D. and RAYCHAUDHURI M.: Hypothyroidism and obesity. Indian J. Endocrinol. Metab., 20 (4): 554-7, 2016.

16- JUNG U.J. and CHOI M.S.: Obesity and its metabolic complications: The role of adipokines and the relationship between obesity, inflammation, insulin resistance, dyslipidemia and nonalcoholic fatty liver disease. Int. J. Mol. Sci., 15 (4): 6184-223, 2014.

17- KITAHARA C.M., TRABERT B., KATKI H.A., CHATURVEDI A.K., KEMP T.J., PINTO L.A., et al.: Body mass index, physical activity, and serum markers of inflammation, immunity, and insulin resistance. CancerEpidemiol Biomarkers Prev., 23 (12): 2840-9, 2014.

18- ANTUNES T.T., GAGNON A., BELL A. and SORISKY A.: Thyroid-stimulating hormone stimulates interleukin6 release from 3T3-L1 adipocytes through a cAMP-protein kinase a pathway. Obesity, 13 (12): 2066-71, 2005.

19- KLOVER P.J., ZIMMERS T.A., KONIARIS L.G. and MOONEY R.A.: Chronic exposure to interleukin- 6 causes hepatic insulin resistance in mice. Diabetes, 52: 2784-9, 2003.

20- MARTINS L., OLIVEIRA A.S., CRUZ K.C., TORRESLEAL F.L. and MARREIRO D.N.: Obesity, inflammation, and insulin resistance. Braz. J. Pharm. Sci., 50 No.4., 2014.

21- DIMITRIADIS G., MITROU P., LAMBADIARI V., BOUTATI E., MARATOU E., PANAGIOTAKOS D.B., KOUKKOU E., TZANELA M., THALASSINOS N. and RAPTIS S.A.: Insulin action in adipose tissue and muscle in hypothyroidism. J. Clin. Endocrinol. Metab., 91: 49307, 2006.

22- AKSOY N., YELER M.T., AYAN N.N., OZKESKIN A., OZKAN Z. and SERIN N.O.: Association between thyroid hormone levels and insulin resistance and body mass index Pak. J. Med. Sci., 31 (6): 1417-20, 2015.

23- AMITANI M., ASAKAWA A., AMITANI H. and INUI A.: The role of leptin in the control of insulin-glucose axis. Front Neurosci., 7: 51(36), 2013.

24- KAHN B.B. and FLIER J.S.: Obesity and insulin resistance. J. Clin. Invest., 106: 473-81, 2006.

25- GIERACH M., GIERACH J. and JUNIK R.: Insulin resistance and thyroid disorders. Endokrynol. Pol., 65 (1): 70-6, 2014

26- KAPLAN O.1., UZUM A.K., ARAL H., UZUM G., TUNALI V., DEMIR O., PLANCI K.N., KESMEZACAR O. and OZBEY N.C.: Unchanged serum adipokine con- 
centrations in the setting of short-term thyroidectomyinduced hypothyroidism. Endocr. Pract., 18 (6): 887-93, 2012.

27- UN JU JUNG and MYUNG-SOOK CHOI: Obesity and Its Metabolic Complications: The Role of Adipokines and the Relationship between Obesity, Inflammation, Insulin Resistance, Dyslipidemia and Nonalcoholic Fatty Liver. Disease Int. J. Mol. Sci., 15 (4): 6184-223, 2014.

28- TANGVARASITTICH S.: Oxidative stress, insulin resistance, dyslipidemia and type 2 diabetes mellitus. World $\mathrm{J}$. Diabetes, 6 (3): 456-80, 2015.

29- CHEN Y., WU X., WU R., SUN X., YANG B., WANG Y., et al.: Changes in profile of lipids and adipokines in patients with newly diagnosed hypothyroidism and hyperthyroidism. Sci. Rep., 6: 26174, 2016.

30- JAMES S.R., RAY L., RAVICHANDRAN K. and NANDA S.K.: High atherogenic index of plasma in subclinical hypothyroidism: Implications in assessment of cardiovascular disease risk. Indian J. Endocrinol. Metab., 20 (5): 656-61, 2016.

31- OLENYCH L.V.1, PYLYPIV L.I.1, BEK N.S.1 and RADCHENKO O.M. 1: Correlations between lipid metabolism indices in patients with hypertension and hypothyroidism Wiad Lek., 71 (2 pt 1): 281-4, 2018.

32- WULF A., HARNEIT A., KRÖGER M., KEBENKO M., WETZEL M.G. and WEITZEL J.M.: T3-mediated expression of PGC- $1 \alpha$ via a far upstream located thyroid hormone response element. Mol. Cell. Endocrinol., 287: 90-5, 2008.

33- OUCHI N., OHASHI K., SHIBATA R. and MUROHARA T.: Protective roles of adipocytokines and myokines in cardiovascular disease. Circ. J., 80 (10): 2073-80, 2016.

34- YANG W.1, LI Y.1, TIAN T.2, WANG L.2, LEE P.3 and HUA Q.: Serum vaspin concentration in elderly patients with type 2 diabetes mellitus and macrovascular complications. B.M.C. Endocr. Disord., 17 (1): 67, 2017.

35- KIM J.M., KIM T.N. and WON J.C.: Association between serum vaspin level and metabolic syndrome in healthy korean subjects. Metabolic Syndrome and Related Disorders, 11 (6): 385-91, 2013.

36- YAN T., LI L., WANG H., et al.: Correlation between adipocytokines levels and metabolic syndrome in type 2 diabetes mellitus. Nan Fang Yi Ke Da Xue Xue Bao, 34 (2): $275-8,2014$.

37- DIMOVA R.1 and TANKOVA T. 1: The role of vaspin in the development of metabolic and glucose tolerance disorders and atherosclerosis. Biomed. Res. Int., 2015: 823481, 2015.

38- KARBEK B., BOZKURT N.C., TOPALOGLU O., et al.: Relationship of vaspin and apelin levels with insulin resistance and atherosclerosis in metabolic syndrome. Minerva Endocrinologica, 39 (2): 99-105, 2014.

39- GONZALEZ C.R., CAMINOS J.E., VAZQUEZ M.J., GARCES M.F., CEPEDA L.A., ANGEL A., GONZALEZ A.C., GARCIA-RENDUELES M.E., SANGIAO-ALVARELLOS S., LOPEZ M., et al.: Regulation of visceral adipose tissue-derived serine protease inhibitor by nutritional status, metformin, gender and pituitary factors in rat white adipose tissue. J. Physiol., 587: 3741-50, 2009.
40- HANDISURYA A., RIEDL M., VILA G., MAIER C., et al.: Serum vaspin concentrations in relation to insulin sensitivity following RYGB induced weight loss. Obesity Surgery, 20: 198-203, 2010.

41- CINAR N., GULCELIK N.E., AYDIN K., AKIN S., USMAN A. and GURLEK A.: Serum vaspin levels in hypothyroid patients. Eur. J. Endocrin., 165: 563-65, 2011.

42- MARTINEZ-DEMENA R.1, ANEDDA A.2, CADENAS S.3 and OBREGON M.J.4: TSH effects on thermogenesis in rat brown adipocytes. Mol. Cell Endocrinol., 15; 404: 151-8, 2015.

43- SHAKER O.G. and SADIK N.A.: Vaspin gene in rat adipose tissue: Relation to obesity-induced insulin resistance. Mol. Cell. Biochem., 373: 229-39, 2013.

44- EVA O. MELIN, HANS O. THULESIUS, MAGNUS HILLMAN, MONA LANDIN-OLSSON and MARIA THUNANDER: Abdominal obesity in type 1 diabetes associated with gender, cardiovascular risk factors and complications, and difficulties achieving treatment targets: A cross sectional study at a secondary care diabetes clinic B.M.C. Obes., 5: 15, 2018.

45- KRALISCH S. and FASSHAUER M.: Adipocyte fatty acid binding protein: A novel adipokine involved in the pathogenesis of metabolic and vascular disease. Diabetologia, 56 (1): 10-21, 2013.

46- MELINO M., GADD V.L., WALKER G.V., et al.: Macrophage secretory products induce an inflammatory phenotype in hepatocytes. World J. Gastroenterol., 18: 173244, 2012.

47- YING HUANG, ZHEN YANG, ZI YE, QIN LI, JIE WEN, XIAOMING TAO, LILI CHEN, MIN HE, XUANCHUN WANG, et al.: Lipocalin-2, glucose metabolism and chronic low-grade systemic inflammation in Chinese people. Cardiovasc Diabetol., 11: 11, 2012.

48- PATSAOURA A., TATSI E., MARGELI A.1, KANAVAKI I.1, DELAPORTA P., KYRIAKOPOULOU D., KOURAKLIS-SYMEONIDIS A., KATTAMIS A. and PAPASSOTIRIOU I.: Plasma neutrophil gelatinase-associated lipocalin levels are markedly increased in patients with non-transfusion-dependent thalassemia: Lack of association with markers of erythropoiesis, ironmetabolism and renal function. Clin. Biochem., 47 (12):1060-4, 2014.

49- ZHANG C. and RAWAL S.: Dietary iron intake, iron status, and gestational diabetes. Am. J. Clin. Nutr., 106 (Suppl 6): 1672S-1680S, 2017.

50- YAN Q.W.1, YANG Q., MODY N., GRAHAM T.E., HSU C.H., XU Z., HOUSTIS N.E., KAHN B.B., ROSEN E.D.: The adipokine lipocalin 2 is regulated by obesity and promotes insulin resistance. Diabetes, 56 (10): 2533-40, 2007.

51- ELGADI A., ZEMACK H., MARCUS C. and NORGREN S.: Tissue-specific knockout of TSHr in white adipose tissue increases adipocyte size and decreases TSH-induced lipolysis. Biochem. Biophys. Res. Commun., 393 (3): 526-30, 2010

52- ZORLU M.1, KISKAC M., KARATOPRAK C., KESGIN S., CAKIRCA M., YILDIZ K., ARDIC C., CIKRIKCIOGLU M.A.8 and ERKOC R.: Assessment of serum 
apelin and lipocalin-2 levels in patients with subclinical hypothyroidism. Ann. Endocrinol. (Paris), 75 (1): 10-4, 2014.

53- CHENG-YI CHEN, YANG-HSIANG LIN, HSIANGCHENG CHI, YA-HUI HUANG, 3 PEI-JU TAI, 1 CHIAJUNG LIAO, 1 CHUNG-YING TSAI, et al.: Thyroid hormone-mediated regulation of lipocalin 2 through the Met/FAK pathway in liver cancer. Oncotarget, 6 (17): 15050-64, 2015.

54- BERTRAND C., VALET P.1 and CASTAN-LAURELL
I.: Apelin and energy metabolism. Front Physiol., 6: 115, 2015.

55- BOUCHER J., MASRI B., DAVIAUD D., GESTA S., GUIGNÉ C., MAZZUCOTELLI A., et al.: Apelin, a newly identified adipokine up-regulated by insulin and obesity. Endocrinology, 146: 1764-71, 2005.

56- ALI GÜREL, AKIF DOGANTEKIN, YUSUF ÖZKAN and SÜLEYMAN AYDıN: Serum apelin levels in patients with thyroid dysfunction. Int. J. Clin. Exp. Med., 8 (9): $16394-8,2015$

\section{دور التغيرات فى بعض الآديبوكين مع السمنينة

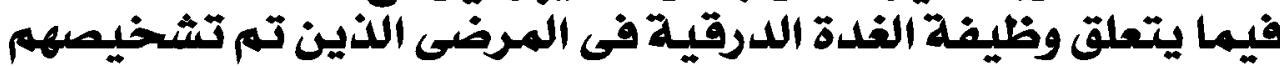 فى وقت مبكر مع قصور الغدة الدرقية العرقية دون السرين تهرى}

الخلفية: يمكن آن تئثر هرمونات الغدة الدرقية على إستقلاب الطاقة. العديد من مرضى السمنة لديهم قصود الغدة الدرقية.

الهدف من الدراسة": تقييم علاقة التغيرات فى مستوى هرمونات الخلايا الشحمية فى السمنة السريرية والعكس بالعكس وعلاقتتها بحالة الغدة الدرقية فى المرضى الذين تم تثخيصهم مبكرا بقصود الغدة الدرقية تحت الإكلينيكى.

المواد والطرق: يشمل هذا العمل •9 آثثى مقسمة إلى ب مجموعات كل •r شخص (المجموعة الآولى) السيطرة الطبيعية (المجموعة الثانية)

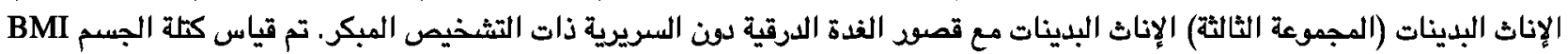

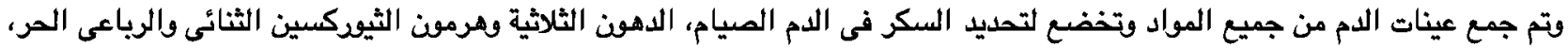

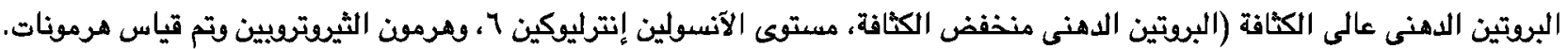
فازيين ولييوكالين r والإبيلين، تم قياس مقاومة اليجنين الآنسولين.

النتائج: آظهرت زيادة معنوية فى المرضى الذين يعانون من السمنة المفرطة مع زيادة معنوية إضافية فى السمنة مع قصور الغدة الدرقية مقارنة مع مجموعة السيطرة فى مؤشر كتلة الجسم.

فازيين ولييوكالين r هرمونات، HOMA-IR, Interleukin-6، صيام الجلوكوذ فى الدم، الآنسولين الصائم، TSH والآبيلين الكوليسترول

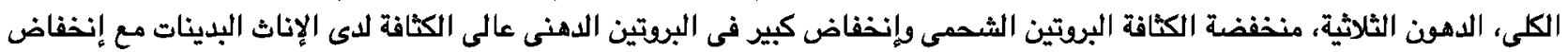

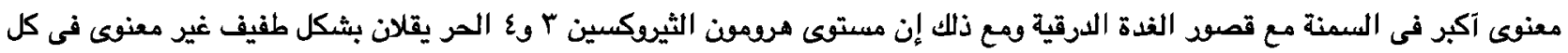

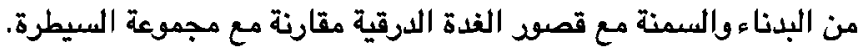

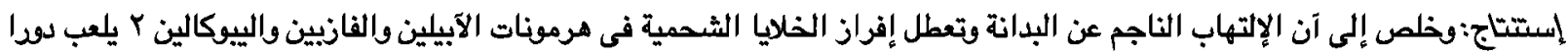

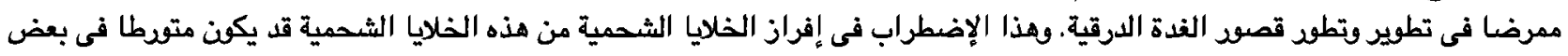
التغيرات الآيضية المرتبطة بحالة قصور الغدة الدرقية. 